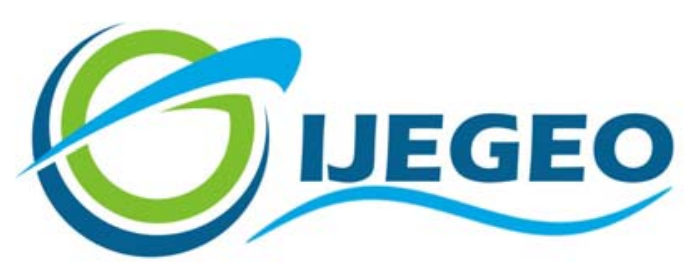

International Journal of Environment and Geoinformatics (IJEGEO) is an international, multidisciplinary, peer reviewed and certified open access journal.

\title{
Impact Analysis of Sanitary Landfill Based Odour in Istanbul Using GIS
}

\author{
Merve Korkutan, Ahmet Özgür Doğru and Çiğdem Göksel \\ Editors \\ Prof. Dr. Cem Gazioğlu, Prof. Dr. Dursun Zafer Şeker, Prof. Dr. Ayşegül Tanık, \\ Prof. Dr. Şinasi Kaya, Assist. Prof. Dr. Volkan Demir
}

\section{Scientific Committee (2018)}

Dr. Abdullah Aksu, Prof. Dr. Bedri Alpar, Prof. Dr. Gülşen Altuğ, Prof. Dr. Lale Balas, Prof. Dr. Can Balas, Prof. Dr. Levent Bat, Prof. Dr. Bülent Bayram, Prof. Dr. Nuray Çağlar, Prof. Dr. Jadunandan Dash, Prof. Dr. A. Evren Erginal, Dr. Dieter Fritsch, Dr. Amin Gharehbaghi, Assoc. Prof. Dr. Tolga Görüm, Prof. Dr. Melike Gürel, Dr. Hakan Kaya, Prof. Dr. Fatmagül Kılıç, Assoc. Prof. Dr. Maged Marghany, Prof. Dr. Nebiye Musaoğlu, Prof. Dr. Masafumi Nakagawa, Prof. Dr. Haluk Özener, Prof. Dr. Erol Sarı, Prof. Dr. Elif Sertel, Prof. Dr. Nüket Sivri, Assoc. Prof. Dr. Füsun Balık Şanlı, Prof. Dr. Uğur Şanlı, Assoc. Prof. Dr. Hasan Özdemir, Prof. Dr. Taşkın Kavzoğlu, Msc. Mustafa Üstüner, Assoc. Prof. Dr. Oral Yağcı, Prof. Dr. Seyfettin Taş, Assoc. Prof. Dr. Ömer Suat Taşkın, Assoc. Prof. Dr. İ. Noyan Yılmaz, Dr. Baki Yokeş, Dr. Sibel Zeki 


\title{
Impact Analysis of Sanitary Landfill Based Odour in Istanbul Using GIS
}

\section{Merve Korkutan, Ahmet Özgür Doğru, Çiğdem Göksel}

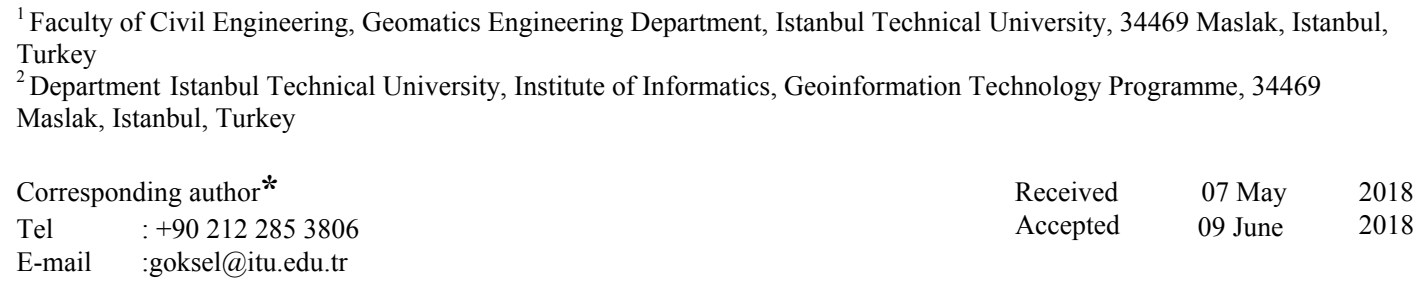

\begin{abstract}
The environmental problems caused by accelerated urbanization in recent years have reached vital limits. As the population increases in the cities, the problem of waste disposal and storage arises. The incorrect selection of sanitary landfill sites affects human and other living creatures because of the malodour sprawling from these sites. Such problems in particularly appears in metropoles as Istanbul. The main objective of this study is to analyse potential impact of the malodour emitted by the second degree of sanitary landfills, Odayeri and Kömürcüoda located in Istanbul. In this context, the population and land use/land cover (LU/LC) characteristics lands were estimated with in a multiple ring buffer located around the landfill areas using Open Source GIS Technology. As a conclusion the neighbourhoods affected by two sanitary landfills in different buffer zones examined by comparing the population and different LU/LC classes in those areas. This study resulted that in case of a potential malodour emitted from landfill areas, the most affected neighbourhood is Göktürk Merkez for Odayeri, while Avcıkoru is for Kömürcüoda. Total population and the characteristics of the affected lands were determined and explained in detail within the context of the study.
\end{abstract}

Keywords: Impact analysis, Land cover, Land use, Odour mapping, Open Source GIS

\section{Introduction}

Odours are a specific type of pollution in terms of the annoyance caused by them is mostly a derivative of their subjective perception (Sówka, 2013). This aspect also has a inevitable effect on our perception of the built environment in terms of smellscapes which refers to the olfactory landscapes of the cities (Porteous, 1985). The experience of urban life also depends on the perception of smell and that will conclude in the studies according to the urban design combined with sensory information provided or observed (Henshaw, 2014).

Several environmental factors such as, terrain structure (land use / land cover characteristics, topography and morphology), atmospheric conditions, the severity of the odour, etc., influence the propagation direction and speed of the odour. Since these parameters play an important role in modelling of odour intensity, the prediction and modelling of the spread of the odour is relatively difficult and the modelling process requires interdisciplinary research can improve the closest model to reality (Göksel et al., 2018).

Rapid urbanization, increasing population and distorted settlement have been the triggering factors in the creation of sustainable smart cities (Burak et al., 2004). As the consumption of the growing population increases, the sanitary landfills have become a significant problem in cities (Alpar et al., 2003; Gazioğlu et al., 2016). The complications and problems that based on the odour in the urban areas are also considered as an affecting parameter of the urban planning process. By identifying its range 
and spatio-temporal variations, it could be taken into consideration by planners in urban development strategies and land use decisions (Gazioğlu et al., 1997; Badach et al., 2018). This problem further increases when the location of the sanitary landfill areas is not determined precisely by considering their potential impacts over surrounding populations and the environment.

Odour monitoring should be an important element in the evaluation of environmental quality in numerous current urban development strategies, for example in the widely advocated compact city policy or in the case of introduction of housing into industrial estates and the promotion of mixed-use development (Korthals Altes and Tambach, 2008; Stead and Hoppenbrouwer,2004). According to experts at World Health Organisation, odour nuisance significantly decreases the quality of life (WHO - World Health Organization, 2000).

Methane and carbon dioxide are the major gases formed by domestic solid wastes in landfill areas and they damage the human health (Ozcan et al., 2006). According to the global researches, it causes various diseases such as respiratory insufficiency, cancer, heart diseases. Particulate air pollution causes about $3 \%$ of mortality from cardiopulmonary disease, about $5 \%$ of mortality from cancer of the trachea, bronchus, and lung, and about $1 \%$ of mortality from acute respiratory infections in children under the age of 5 (Cohen et al., 2005). Malodour not only affects people, but plants and animals in the surrounding environment as well. According to the researches, olfactory signals, often in synergy with visual signals, mediate the interactions between plants and animals. Airborne pollutants may disrupt chemical information transfer between flowering plants and flower visitors. In addition to this, it can disrupt the transmission between animals (Jurgens and Bischoff, 2017). Therefore, several methodologies were proposed in order to remove the malodour in municipal waste landfill areas (Huang et al., 2010). Additionally, the potential or existing malodour in landfill areas were tried to be modelled based on the effecting parameters (Sarkar et al., 2003; Nicolas et al., 2006). Most of the research has focused on odour measurements and emission values (Romain et al., 2008; Capelli et al., 2013). Since the overall context included location based issues and their solutions, Geographical Information System (GIS) technology has been used in different phases of the Sanitary Landfill management (Intarakosit, 2010; Alanbari et al., 2014). GIS is a computerized databased management system for capture, storage, retrieval, manipulation, analysis and display of spatial data (Clarke, 1986). It is considered as a decision support system supporting the decision-making processes as site selection, impact analysis, planning and managing the environmental issues by integrating, analysing and displaying spatial data in an understandable form for a large variety of cases as transportation, health, environmental management, planning and etc. (Seker et al., 2003; Tortum et al., 2011; Hamamc1 et al., 2017; Dogru et al., 2017). As well as the commercial solutions, Open Source GIS is currently arising in such applications. There are well-known benefits of open source software, such as cost savings, vendor independence, and open standards (Nagy et al., 2010). It is suitable for use in different analyses of demographic data, spatial data, LU/LC maps and many more data types (Islam, K. et all., 2016).

This study aims to estimate the population at the potential risk of malodour exposition based on two landfill areas in Istanbul using open source GIS solutions. The study also aims to determine the characteristics of the lands that can be affected by malodour based on the selected sites using remotely sensed images.

\section{Data and Methodology}

Istanbul is the most populated city of Turkey with a population of around 15 million living on around $5.750 \mathrm{~km}^{2}$. For the study, the seconddegree regular sanitary landfills of Istanbul metropolitan area with $2,786 / \mathrm{km}^{2}$ population density were selected. Because of quick monetary improvement and urbanization in Istanbul the sum of wastes produced has extraordinarily expanded in the last decade (Saral et al., 2009).

The Odayeri Sanitary Landfill located on the European side and the Kömürcüoda Sanitary 
Landfill is on the Asian side of the city and they are the two basic landfill facilities serving the most part of Istanbul. Based on the existing waste treatment system in the city, 12390 tons of municipal solid waste per day from eight municipal waste transfer stations serving in various parts of the city by the municipal waste trucks are transported to the Regular Storage Areas along the European and Asian sides. The average amount of waste in the Odayeri sanitary landfill is 11154 tons/day whereas it is 5989 tons/day in Kömürcüoda. The study area and location of the sanitary landfills are presented in Figure 1.

The Spatial data used in the study included vector polygons of the landfill areas and administrative boundaries in city and the neighbourhood levels. The stated data was provided by the Istanbul Metropolitan Municipality. Additionally, LU/LC map of the study area produced using 2016 dated Landsat 8 Operational Land Imager (OLI) data were also used in the study to determine the LU/LC characteristics of the affected lands. The stated data included $9 \mathrm{LU} / \mathrm{LC}$ classes as waterbodies, forests, green areas, agriculture, urban build-up, roads, sand dunes, bare land, and open mining areas, based on the CORINE LU/LC classes. Finally, tabular data including population by neighbourhood in the year of 2016 were also integrated in to the implemented GIS in order to estimate the population under the potential risk of malodour exposition. Population data obtained from Turkish Statistical Institute. The implementation is realized using QGIS, a free and Open Source Geographic Information System licensed under the GNU General Public License and produced by an official project of the Open Source Geospatial Foundation (OSGeo) solutions (Athan et al., 2004).

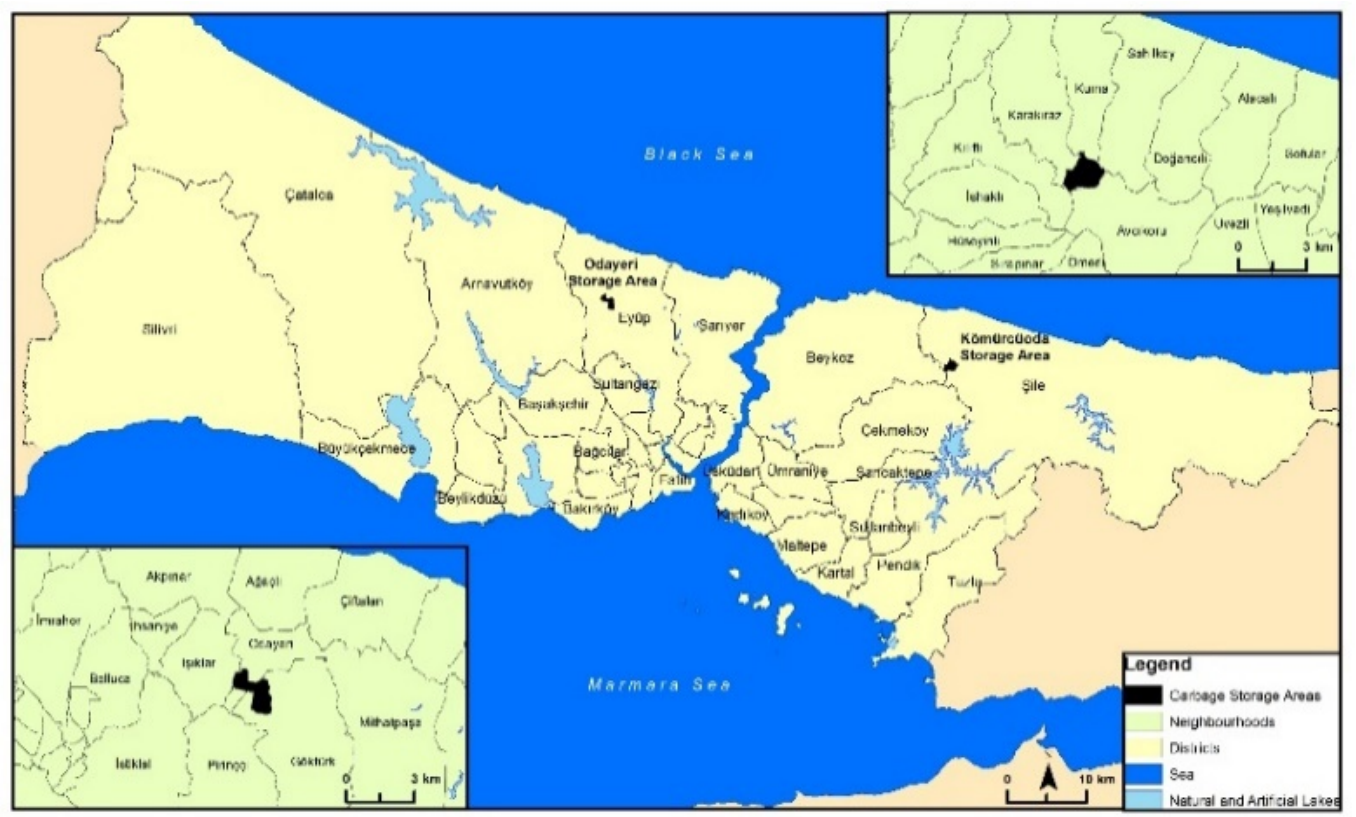

Fig 1. Locations of the selected sanitary landfills in Istanbul

The workflow of the applied methodology is presented in the Figure 2. As indicated in the figure All data were transferred to QGIS 2.18 software and various methods were applied. Firstly, the buffer zones of $1 \mathrm{~km}, 2 \mathrm{~km}, 4 \mathrm{~km}$ and $6 \mathrm{~km}$ radius were obtained by buffer analysis on the sanitary landfills. Resulted buffers then overlaid and intersected with the neighbourhood polygons in order to determine the areas under the risk of malodour exposure. On the other hand, LU/LC data was reclassified as urban area, natural area and artificial area in order to determine the potential impact on three main LU/LC classes. In this reclassification process urban build-up layer considered as urban area, natural area included forests, green areas, agriculture, and sand dunes then artificial area composed of roads, bare land, open mining 
areas. Accuracy assessments determine the quality of the information derived from classified remotely sensed data (Congalton and Green, 1999; Foody, 2002). The most widely promoted and used accuracy assessment methods may be derived from a confusion or error matrix. Based on accuracy assessment results LU/LC maps were produced with similar overall accuracy and Kappa statistic values of over $85.00 \%$ and over 0,71 , respectively by using supervised classification methods. Reclassified vector map was also overlaid with the administrative boundaries in

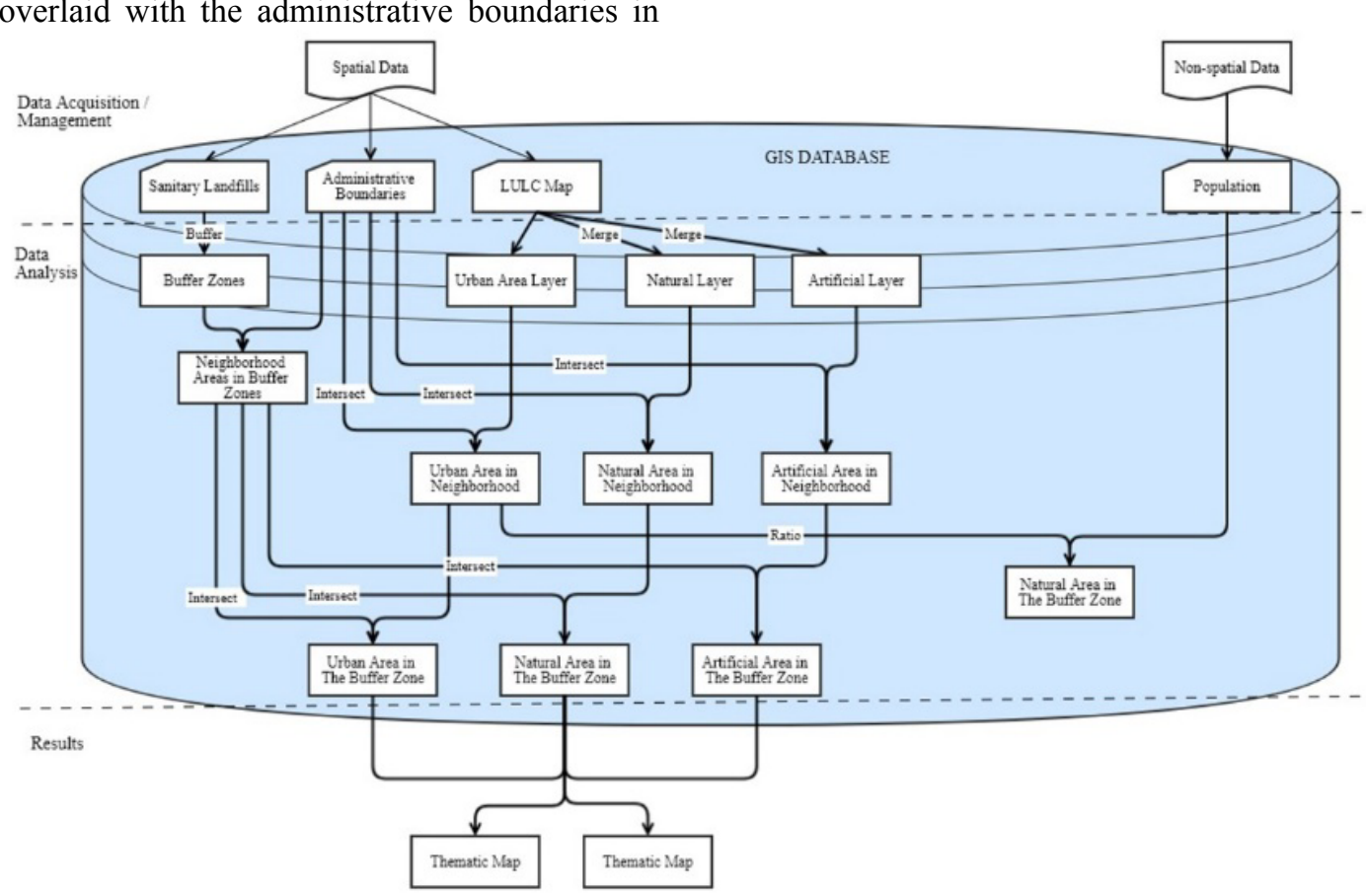

order perform a detailed analysis of the lands under risk in terms of LU/LC characteristics by neighbourhood. Then, effective percentages are calculated by proportioning the data obtained and the areas of influence in the different buffer zones.

In the final stage, the results obtained by making the most affected neighbourhoods from bad odour spread from sanitary landfill and the most terrestrial terrain classifications are presented for discussion.

Fig. 2. Workflow of the methodology

\section{Results and Discussions}

The results of the GIS analysis performed in the study presented as maps in Figure 3. The figure includes landfill area and neighbourhood polygons, buffer zones and reclassified LU/LC classes in two different maps for both study areas. The main results of the applied overlay analysis were the total areas of LU/LC classes by neighbourhood in determined buffer zones. The detailed results of the GIS analysis were presented in Table 1 and Table 2 for Odayeri and Kömürcüoda sanitary landfill areas 


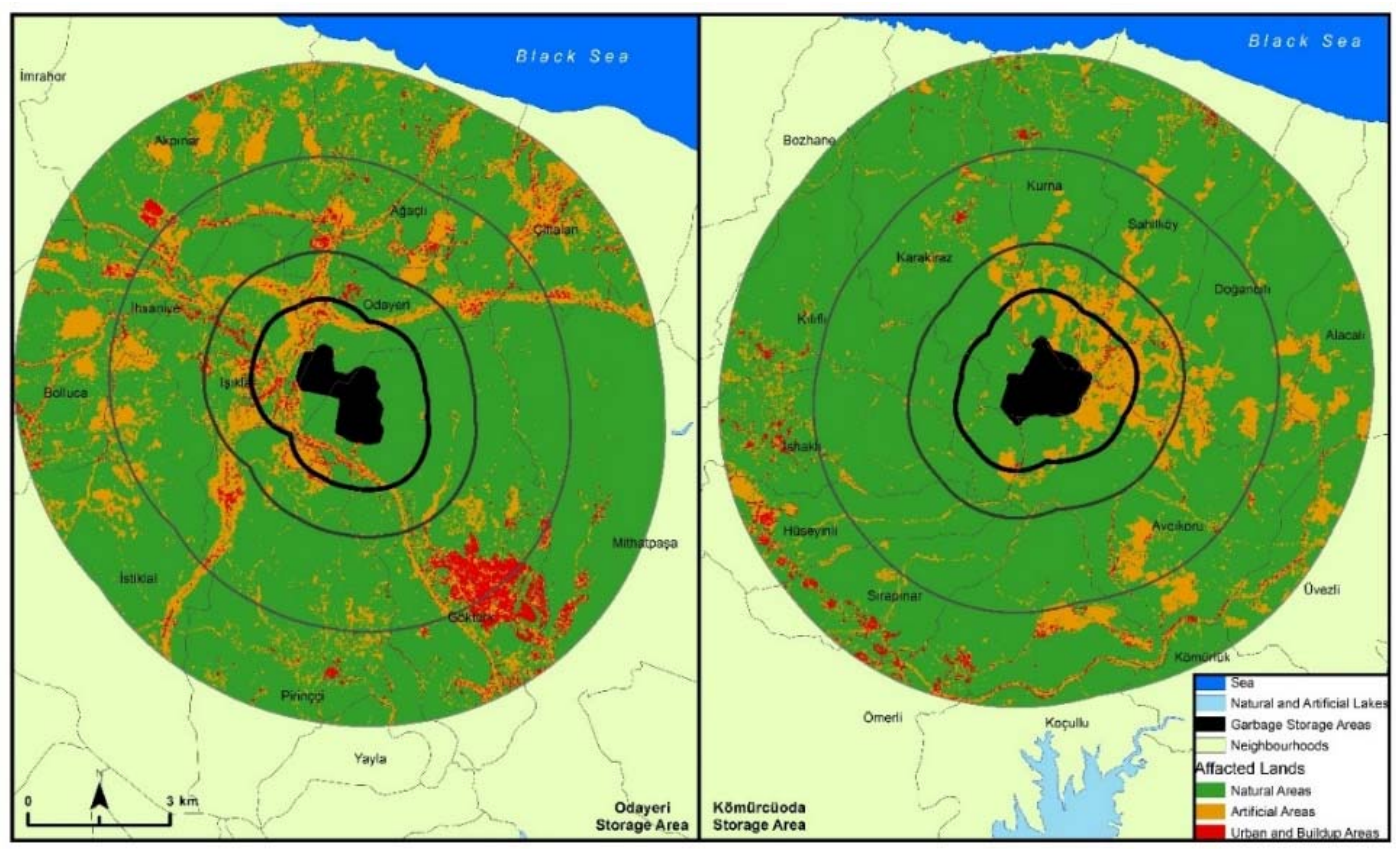

Figure 3. Affected lands by LU/LC class

When the results examined by considering the LU/LC classes of the affected lands, according to the Table 1, the urban area most affected by the potential malodour is Işıklar neighbourhood for $1 \mathrm{~km}, 2 \mathrm{~km}$ of buffer zones, and Göktürk Merkez for $4 \mathrm{~km}, 6 \mathrm{~km}$ of buffer zones for Odayeri Sanitary Landfill. Additionally, the natural area most affected by malodour is Göktürk Merkez for $1 \mathrm{~km}, 2 \mathrm{~km}$ and $4 \mathrm{~km}$ of buffer zones, and Mithatpaşa for $6 \mathrm{~km}$ of buffer zone. The artificial area most affected by malodour is Işıklar for $1 \mathrm{~km}$ and $2 \mathrm{~km}$ of buffer zones, Pirinçci for $4 \mathrm{~km}$ of buffer zone and Çiftalan for $6 \mathrm{~km}$ of buffer zone for Odayeri Sanitary Landfill.

The urban area most affected by malodour is Sahilköy neighbourhood for $1 \mathrm{~km}, 2 \mathrm{~km}$ of buffer zones, Avcikoru for $4 \mathrm{~km}$ of buffer zone and Ömerli for $6 \mathrm{~km}$ of buffer zones for Kömürcüoda Sanitary Landfill as presented in Table 2. The most affected natural areas are included in Kılıçlı for $1 \mathrm{~km}, 6 \mathrm{~km}$ of buffer zones, and in Avcikoru for $2 \mathrm{~km}, 4 \mathrm{~km}$ of buffer zone for the same sanitary landfill. Finally, the artificial areas are mostly affected in Sahilköy for $1 \mathrm{~km}, 2 \mathrm{~km}$ of buffer zones, Avc1koru for 4 $\mathrm{km}$ of buffer zone and Ömerli for $6 \mathrm{~km}$ of buffer zone for Kömürcüoda.
The population affected by the potential malodour were roughly estimated by multiplying the percentages of the affected urban areas with the total population of the neighbourhood. The results were also presented in Table 1 and Table 2 for Odayeri and Kömürcüoda Sanitary Landfill Areas respectively. Based on the Table 1, Işıklar neighbourhood within the $1 \mathrm{~km}$ and $2 \mathrm{~km}$ buffer zones is the most affected area. The affected population rate is $39 \%$ and $77 \%$ respectively. With $65 \%$ of the population in the $4 \mathrm{~km}$ buffer zone is the most affected neighbourhood is İhsaniye. With $48 \%$ of the population in the 6 $\mathrm{km}$ buffer zone is the most affected neighbourhood is Çiftalan.

The results obtained when considering the population for Kömürcüoda Sanitary Landfill are as follows. Avc1koru neighbourhood within the $1 \mathrm{~km}$ and $4 \mathrm{~km}$ buffer zones is the most affected area. The affected population rate is $15 \%$ and $40 \%$ respectively. With $9 \%$ of the population in the $2 \mathrm{~km}$ buffer zone is the most affected neighbourhood is Sahilköy. With $85 \%$ of the population in the $6 \mathrm{~km}$ buffer zone is the most affected neighbourhood is Sirapınar. 
Table 1. Statistical results of GIS analyses of Odayeri sanitary landfill

\begin{tabular}{|c|c|c|c|c|c|c|c|c|c|c|}
\hline $\begin{array}{c}\text { Buffer } \\
\text { Distance }\end{array}$ & $\begin{array}{c}\text { Neighbourhoo } \\
\text { d } \\
\text { Name }\end{array}$ & $\begin{array}{l}\text { Total } \\
\text { Urban } \\
\text { Area } \\
\text { (ha) }\end{array}$ & $\begin{array}{c}\text { Total } \\
\text { Population }\end{array}$ & $\begin{array}{l}\text { Affected } \\
\text { Urban } \\
\text { Area (ha) }\end{array}$ & $\begin{array}{c}\text { Affected } \\
\text { Populatio } \\
n\end{array}$ & $\begin{array}{c}\text { Affected } \\
\text { Populatio } \\
\text { n (\%) }\end{array}$ & $\begin{array}{l}\text { Affected } \\
\text { Natural } \\
\text { Area (ha) }\end{array}$ & $\begin{array}{l}\text { Affected } \\
\text { Natural } \\
\text { Area (\%) }\end{array}$ & $\begin{array}{c}\text { Affecte } \\
\text { d } \\
\text { Artifici } \\
\text { al Area } \\
\text { (ha) }\end{array}$ & $\begin{array}{l}\text { Affected } \\
\text { Artificial } \\
\text { Area (\%) }\end{array}$ \\
\hline \multirow{4}{*}{$1 \mathrm{~km}$} & Odayeri & 49,4 & 228 & 13,6 & 62 & 27 & 170,3 & 32 & 70,8 & 37 \\
\hline & $\begin{array}{l}\text { Göktürk } \\
\text { Merkez }\end{array}$ & 288,9 & 30782 & 15 & 1596 & 5 & 377,7 & 17 & 32,1 & 8 \\
\hline & Pirinççi & 89,1 & 3842 & 7,1 & 305 & 8 & 28,7 & 1 & 29,6 & 8 \\
\hline & Işıklar & 68,6 & 550 & 26,9 & 215 & 39 & 87,9 & 13 & 92,6 & 29 \\
\hline \multirow{4}{*}{$2 \mathrm{~km}$} & Odayeri & 49,4 & 228 & 14,6 & 67 & 30 & 239,3 & 45 & 60,5 & 26 \\
\hline & $\begin{array}{l}\text { Göktürk } \\
\text { Merkez }\end{array}$ & 288,9 & 30782 & 2,6 & 277 & 1 & 490,5 & 22 & 30,8 & 8 \\
\hline & Pirinççi & 89,1 & 3842 & 4,9 & 211 & 5 & 224,0 & 10 & 55,7 & 15 \\
\hline & Işıklar & 68,6 & 550 & 26,3 & 210 & 38 & 233,1 & 34 & 139,0 & 44 \\
\hline \multirow{11}{*}{$4 \mathrm{~km}$} & Odayeri & 49,4 & 228 & 18,4 & 84 & 37 & 107,7 & 20 & 59,4 & 26 \\
\hline & $\begin{array}{l}\text { Göktürk } \\
\text { Merkez }\end{array}$ & 288,9 & 30782 & 123,2 & 13125 & 43 & 764,5 & 35 & 132,5 & 34 \\
\hline & Pirinççi & 89,1 & 3842 & 16,9 & 726 & 19 & 723,0 & 33 & 137,7 & 36 \\
\hline & Işıklar & 68,6 & 550 & 15,4 & 123 & 22 & 362,2 & 53 & 83,1 & 26 \\
\hline & A ğaçlı & 68,7 & 979 & 36,9 & 525 & 54 & 393,1 & 36 & 130,4 & 35 \\
\hline & Çiftalan & 91,5 & 126 & 9,1 & 12 & 10 & 198,0 & 18 & 37,6 & 6 \\
\hline & Mithatpaşa & 143,8 & 5090 & 0,9 & 31 & 1 & 439,9 & 10 & 16,6 & 6 \\
\hline & $\begin{array}{c}\text { Boğazköy } \\
\text { İstiklal }\end{array}$ & 128,2 & 8009 & 2,3 & 141 & 2 & 451,1 & 19 & 80,0 & 18 \\
\hline & Bolluca & 77,0 & 6156 & 2,1 & 165 & 3 & 9,6 & 1 & 13,3 & 5 \\
\hline & İhsaniye & 29,9 & 174 & 19,5 & 113 & 65 & 220,2 & 66 & 92,4 & 70 \\
\hline & Akpinar & 101,7 & 1143 & 5,2 & 58 & 5 & 190,0 & 10 & 26,3 & 4 \\
\hline \multirow{12}{*}{$6 \mathrm{~km}$} & $\begin{array}{l}\text { Göktürk } \\
\text { Merkez }\end{array}$ & 288,9 & 30782 & 119,7 & 12750 & 41 & 409,4 & 19 & 101,6 & 26 \\
\hline & Pirinççi & 89,1 & 3842 & 17,1 & 735 & 19 & 792,0 & 36 & 95,3 & 25 \\
\hline & A ğaçlı & 68,7 & 979 & 23,3 & 331 & 34 & 636,9 & 59 & 143,7 & 39 \\
\hline & Çiftalan & 91,5 & 126 & 45,0 & 61 & 48 & 511,0 & 47 & 218,8 & 36 \\
\hline & Mithatpaşa & 143,8 & 5090 & 34,0 & 1203 & 24 & 1282,5 & 30 & 47,8 & 19 \\
\hline & $\begin{array}{c}\text { Boğazköy } \\
\text { İstiklal }\end{array}$ & 128,2 & 8009 & 8,2 & 510 & 6 & 714,3 & 30 & 141,8 & 33 \\
\hline & Bolluca & 77,0 & 6156 & 26,1 & 2084 & 34 & 622,2 & 77 & 146,4 & 57 \\
\hline & İhsaniye & 29,9 & 174 & 10,4 & 60 & 34 & 113,8 & 34 & 39,2 & 30 \\
\hline & Akpinar & 101,7 & 1143 & 30,0 & 337 & 29 & 742,6 & 38 & 188,1 & 30 \\
\hline & Yayla & 76,5 & 8112 & 0,4 & 44 & 1 & 56,1 & 18 & 4,6 & 6 \\
\hline & İmrahor & 285,0 & 8458 & 0,5 & 15 & 0 & 13,7 & 1 & 5,5 & 0 \\
\hline & Mavigöl & 63,4 & 5019 & 1,9 & 151 & 3 & 0,6 & 1 & 0,1 & 0 \\
\hline
\end{tabular}

When the results for both landfills are taken into consideration, the impacts of natural areas and non-natural areas vary. The rate of impact of both natural and artificial sites reveals which neighbourhoods are more critical. Mithatpaşa, which is located in the 6 $\mathrm{km}$ buffer area, is the most affected natural area (ha) from malodour spreading from Odayeri Sanitary Landfill. On the other hand, the most affected artificial area (ha) is in the Çiftalan neighbourhood, which is located in the buffer area of $6 \mathrm{~km}$. The natural area (ha) most affected by the malodour from the Kömürcüoda Sanitary Landfill is Kılıçlı, which is located in the buffer area of $6 \mathrm{~km}$. On the other hand, the artificial area (ha) that is most affected is Avc1koru, located in a buffer area of $4 \mathrm{~km}$. 
Table 2. Statistical results of GIS analyses of Kömürcüoda sanitary landfill

\begin{tabular}{|c|c|c|c|c|c|c|c|c|c|c|}
\hline $\begin{array}{l}\text { Buffer } \\
\text { Distanc } \\
\text { e }\end{array}$ & $\begin{array}{c}\text { Neighbourhoo } \\
\text { d } \\
\text { Name }\end{array}$ & $\begin{array}{c}\text { Total } \\
\text { Urban } \\
\text { Area (ha) }\end{array}$ & $\begin{array}{c}\text { Total } \\
\text { Population }\end{array}$ & $\begin{array}{l}\text { Affected } \\
\text { Urban } \\
\text { Area (ha) }\end{array}$ & $\begin{array}{c}\text { Affected } \\
\text { Population }\end{array}$ & $\begin{array}{c}\text { Affected } \\
\text { Population } \\
(\%)\end{array}$ & $\begin{array}{l}\text { Affected } \\
\text { Natural } \\
\text { Area (ha) }\end{array}$ & \begin{tabular}{|c|} 
Affected \\
Natural \\
Area \\
$(\%)$ \\
\end{tabular} & $\begin{array}{l}\text { Affected } \\
\text { Artificial } \\
\text { Area (ha) }\end{array}$ & $\begin{array}{l}\text { Affected } \\
\text { Artificial } \\
\text { Area (\%) }\end{array}$ \\
\hline \multirow{5}{*}{$1 \mathrm{~km}$} & Kurna & 17,4 & 132 & 2,1 & 16 & 12 & 86,8 & 8 & 62,7 & 29 \\
\hline & Sahilköy & 76,7 & 668 & 8,3 & 72 & 11 & 30,4 & 2 & 99,8 & 20 \\
\hline & Avcikoru & 25,3 & 95 & 3,9 & 14 & 15 & 153,8 & 10 & 89,0 & 23 \\
\hline & Kilıçlı & 14,8 & 556 & 1,3 & 49 & 9 & 167,2 & 11 & 17,9 & 18 \\
\hline & Karakiraz & 42,1 & 294 & 3,0 & 21 & 7 & 135,3 & 8 & 19,3 & 6 \\
\hline \multirow{6}{*}{$2 \mathrm{~km}$} & Kurna & 17,4 & 132 & 1,0 & 7 & 5 & 92,2 & 9 & 49,1 & 22 \\
\hline & Sahilköy & 76,7 & 668 & 7,3 & 63 & 9 & 167,9 & 12 & 158,7 & 32 \\
\hline & Avcıkoru & 25,3 & 95 & 2,4 & 8 & 8 & 292,0 & 18 & 52,0 & 13 \\
\hline & Kilıçli & 14,8 & 556 & 0,1 & 2 & 0 & 215,4 & 14 & 11,2 & 11 \\
\hline & Karakiraz & 42,1 & 294 & 1,2 & 8 & 3 & 189,3 & 11 & 38,4 & 12 \\
\hline & Doğancilı & 39,1 & 642 & 0,5 & 7 & 1 & 5,1 & 0 & 5,8 & 3 \\
\hline \multirow{8}{*}{$4 \mathrm{~km}$} & Kurna & 17,4 & 132 & 1,0 & 7 & 5 & 392,1 & 36 & 30,9 & 14 \\
\hline & Sahilköy & 76,7 & 668 & 1,9 & 16 & 2 & 437,2 & 31 & 73,7 & 15 \\
\hline & Avcıkoru & 25,3 & 95 & 10,1 & 38 & 40 & 629,7 & 40 & 163,1 & 41 \\
\hline & Kilıçli & 14,8 & 556 & 0,1 & 4 & 0 & 305,7 & 20 & 5,4 & 5 \\
\hline & Karakiraz & 42,1 & 294 & 8,2 & 57 & 19 & 620,0 & 36 & 58,2 & 19 \\
\hline & Doğancilı & 39,1 & 642 & 2,9 & 47 & 7 & 559,6 & 43 & 97,7 & 46 \\
\hline & Ömerli & 252,4 & 3888 & 0,4 & 5 & 0 & 384,2 & 10 & 15,2 & 2 \\
\hline & İshaklı & 37,9 & 1235 & 0,8 & 25 & 2 & 493,0 & 46 & 13,9 & 12 \\
\hline \multirow{14}{*}{$6 \mathrm{~km}$} & Kurna & 17,4 & 132 & 1,1 & 8 & 6 & 466,7 & 43 & 57,3 & 26 \\
\hline & Sahilköy & 76,7 & 668 & 9,8 & 85 & 13 & 583,4 & 41 & 74,3 & 15 \\
\hline & Avcikoru & 25,3 & 95 & 8,9 & 33 & 35 & 515,5 & 32 & 88,8 & 23 \\
\hline & Kilıçli & 14,8 & 556 & 11,2 & 421 & 76 & 738,8 & 49 & 45,9 & 46 \\
\hline & Karakiraz & 42,1 & 294 & 5,3 & 37 & 13 & 620,2 & 36 & 29,9 & 10 \\
\hline & Doğanc1lı & 39,1 & 642 & 1,6 & 25 & 4 & 514,0 & 40 & 55,1 & 26 \\
\hline & Ömerli & 252,4 & 3888 & 46,5 & 716 & 18 & 652,1 & 18 & 132,7 & 20 \\
\hline & Sirapınar & 37,4 & 823 & 31,9 & 703 & 85 & 420,2 & 53 & 40,8 & 57 \\
\hline & Hüseyinli & 78,6 & 747 & 26,5 & 252 & 34 & 272,6 & 27 & 68,0 & 33 \\
\hline & İshaklı & 37,9 & 1235 & 21,5 & 700 & 57 & 392,3 & 36 & 58,8 & 53 \\
\hline & Alacalı & 33,6 & 399 & 2,9 & 34 & 9 & 441,2 & 32 & 95,4 & 31 \\
\hline & Üvezli & 30,7 & 320 & 9,5 & 98 & 31 & 348,6 & 27 & 84,9 & 30 \\
\hline & Kömürlük & 9,6 & 208 & 2,3 & 48 & 23 & 127,9 & 12 & 9,7 & 17 \\
\hline & Koçullu & 62,2 & 1318 & 4,2 & 89 & 7 & 135,6 & 14 & 17,6 & 22 \\
\hline
\end{tabular}

\section{Conclusion}

The potential impact of the malodour spread from two main sanitary landfills on population and lands was estimated within this study using a basic methodology supported by the use of GIS. Since the impact analysis of the odour based on several atmospheric and topographic parameters, multidisciplinary studies should be performed using more detailed and accurate input data for obtaining more precise results.

This study presented a general methodology for demonstrating the use of GIS in environmental impact analysis. More detailed works are considered by the authors as the future work.

\section{References}

Alanbari, M.A., Al-Ansari, N., Jasim H.K. 2014. GIS and multicriteria decision analysis for landfill site selection in AlHashimyah Qadaa. Natural Science, 6, 282304.

Alpar, B., Altınok, Y., Gazioğlu, C. and Yücel, ZY. (2003) Tsunami hazard assessment in Istanbul, Journal of Black Sea/Mediterranean Environment, Vol.9(1):3-29.

Athan, T., Ersts, P., Macho, W., Dassau, O., Bruy, A. et al. 2004. QGIS user guide [Online]. Available: https://www.qgis.org/en/site/about/index.ht ml. [Accessed: 20- Dec- 2017]

Badach, J. Kolasinska, P., Paciorek, M., Wojnowski, W., Dymerski, T., Gebicki, J., Dymnicka, M., Namiesnik, J. 2018. A case 
study of odour nuisance evaluation in the context of integrated urban planning. Journal of Environmental Management 213, 417-424

Burak, S., Doğan, E., and Gazioğlu, C. (2004). Impact of urbanization and tourism on coastal environment. Ocean \& Coastal Management 47 (9):, 515-527.

Capelli, L., Sironi, S., Del Rosso, R., Guillot J.M. 2013. Measuring odours in the environment vs. dispersion modelling: A review. Atmospheric Environment 79: 731743.

Clarke, K.C. 1986. Advances in geographic information systems. Computers, Environment and Urban Systems 10: 175184.

Cohen, A.J., Anderson, H.R., Ostro, B., Pandey, K.D., Krzyzanowski, M., Kunzli, N., Gutschmidt, K., Pope, A., Romieu, I., Samet, J.M., Smith, K. 2005. The global burden of disease due to outdoor air pollution. Journal of Toxicology and Environmental Health 68: 1-7. doi: 10.1080/15287390590936166.

Congalton, R. G., and Green, K., 1999, Assessing the Accuracy of Remotely Sensed Data: Principles and Practices, (Boca Raton: Lewis Publishers).

Dogru, A.O., David, R.M., Ulugtekin, N., Goksel, C., Seker, D.Z., Sozen, S. 2017. GIS based spatial pattern analysis: Children with hepatitis A in Turkey. Environmental Research 349-357. doi: 10.1016/j.envres.2017.04.001.

Foody, G. M., 2002, Status of Land Cover Classification Accuracy Assessment. Remote Sensing of Environment, 80, 185201.

Gazioğlu C, Yücel Y Z, Burak S., Okuş, E. and Alpar, B. (1997). Coastline change and inadequate management between Kilyos and Karaburun shoreline. Turkish Journal of Marine Sciences, 3(2): 111-122.

Gazioğlu, C., Akkaya, M.A., Baltaoğlu, S. and Burrak, S.Z. (2016). ICZM and the Sea of Marmara: The İstanbul Case. The Sea of Marmara: Marine Biodiversity, Fisheries, Conservations and Governance (Editors: Özsoy, E., Çağatay, M.N., Balkıs, N., Balkıs Çağlar, N., Öztürk, B.): 935-957

Göksel, Ç., david, RM. And Doğru, AÖ. (2018). Environmental Monitoring of
Spatio-Temporal Changes in Northern Istanbul using Remote Sensing and GIS, International Journal of Environment and Geoinformatics (IJEGEO) Vol.5(1): 94-103.

Hamamc1, S.F., Dogru, A.O., Sari, D., Ozkurt, Nç, Seker, D.Z. 2017. Determining characteristics of lands effected by noise pollution of airports. Fresenius Environmental Bulletin 26: 69-74.

Henshaw, V., 2014. Urban Smellscapes: Understanding and Designing City Smell Environments. Routledge, New York.

Huang, H., Changying, H., Bing, X. 2010. Control Methods Of Odor Pollution In Municipal Domestic Waste Landfill Sites. Environmental Sanitation Engineering.

Intarakosit, E. 2010. GIS-Based Odor impact assessment from biosolids land. Doctor of Philosophy, Dissertation submitted to the Faculty of the Graduate School of the University of Maryland, College Park.

Islam, K., Jasimuddin,M. , Nath. B., Nath,T.K. 2016. Quantitative Assessment of Land Cover Change Using Landsat Time Series Data: Case of Chunati Wildlife Sanctuary (CWS), Bangladesh. International Journal of Environment and Geoinformatics 3 (2), 4555

Jurgens, A., Bischoff, M. 2017. Changing odour landscapes: The effect of anthropogenic volatile pollutants on plantpollinator olfactory communication. Functional Ecology 31: 56-64. doi: 10.1111/1365-2435.12774.

Korthals Altes, W.K. \& Tambach, M. 2008. Municipal strategies for introducing housing on industrial estates as part of compact-city policies in the Netherlands. Cities,25(4),218-229. doi:10.1016/j.cities.2008.04.005

Nagy, B.D., Yassin, A.M., Bhattacherjee, A. 2010. Organizational adoption of open source software: Barriers and Remedies. Communications of the ACM 53: 148-151. Doi: 10.1145/1666420.1666457

Nicolas, J., Craffe, F., Romain, A.C. 2006. Estimation of odor emission rate from landfill areas using the sniffing team method. Waste Management 26: 1259-1269.

Ozcan H.K., Borat M., Sezgin N., Nelioglu S., Demir G. 2006. Determination of seasonal variations of major landfill gas in Istanbul Kemerburgaz - Odayeri solid waste landfill. 
Fresenius Environmental Bulletin 15: 272276.

Porteous, J.D. $1985 . \quad$ Smellscape. Progress in Physical Geography: Earth and Environment. 9(3). 356-378

Romain, A.C., Delva, J., Nicolas, J. 2008. Complementary approaches to measure environmental odours emitted by landfill areas. Sensors and Actuators B: Chemical 131: 18-23.

Saral, A., Demir, S., Y1ldı, S. 2009. Assessment of odorous VOCs released from a main MSW landfill site in Istanbul-Turkey via a modelling approach. Journal of Hazardous Materials 168, 338-345

Sarkar, U., Hobbs, S.E., Longhurst, P. 2003. Dispersion of odour: A case study with a municipal solid waste landfill site in North London, United Kingdom. Environmental Management 68: 153-160.

Seker, D.Z., Kabdasli, S., Rudvan, B. 2003. Risk assessment of a dam-break using GIS technology. Water Science and Technology 48: 89-95.

Sówka, I. 2013. Industrial activities. Odour impact assessment handbook. pp. 249-256.

Stead, D., Hoppenbrouwer, E., 2004. Promoting an urban renaissance in England and The Netherlands. Cities 21, 119e136. https://doi.org/10.1016/j.cities.2004.01.005.

Tortum, A., Kabakus, N., Codur, M.Y., Atalay, A., Ulugtekin, N. 2011. Clustering analysis of the districts in Erzurum for traffic accidents between 2002 and 2007. Scientific Research and Essays 6: 2850-2857.

WHO - World Health Organization, 2000. Air Quality Guidelines for Europe. European Series, second ed. WHO Regional Publications, p. 91. https://doi.org/10.1007/BF02986808. 